\title{
Therapeutic Renin Inhibition in Diabetic Nephropathy-A Review of the Physiological Evidence
}

\begin{abstract}
Bianca Domingues Massolini1,2†, Stephanie San Gregorio Contieri1,2†, Giulia Severini Lazarini ${ }^{1,2 \dagger}$, Paula Antoun Bellacosa ${ }^{1,2 t}$, Mirela Dobre ${ }^{3}$, Georg Petroianu ${ }^{4}$, Andrei Brateanu ${ }^{5}$, Luciana Aparecida Campos ${ }^{1,2,6}$ and Ovidiu Constantin Baltatu ${ }^{1,2,4 *}$

${ }^{1}$ Center of Innovation, Technology and Education-CITÉ, São José dos Campos Technology Park, São José dos Campos, São Paulo, Brazil, ${ }^{2}$ Institute of Biomedical Engineering, Anhembi Morumbi University, Laureate International Universities, São José dos Campos, São Paulo, Brazil, ${ }^{3}$ Division of Nephrology and Hypertension, University Hospitals, Cleveland, OH, United States, ${ }^{4}$ College of Medicine and Health Sciences, Khalifa University, Abu Dhabi, United Arab Emirates, ${ }^{5}$ Medicine Institute, Cleveland Clinic, Cleveland, $\mathrm{OH}$, United States, ${ }^{6}$ College of Health Sciences, Abu Dhabi University, Abu Dhabi, United Arab Emirates
\end{abstract}

OPEN ACCESS

Edited by:

Joaquin Garcia-Estañ University of Murcia, Spain

Reviewed by:

Carlos P. Vio,

Pontifical Catholic University of Chile,

Chile

Bruno Vogt,

University of Bern, Switzerland

*Correspondence:

Ovidiu Constantin Baltatu

ovidiu.baltatu@ku.ac.ae;

ocbaltatu@gmail.com

tThese authors have contributed equally to this work

Specialty section:

This article was submitted to Integrative Physiology,

a section of the journal

Frontiers in Physiology

Received: 18 November 2019

Accepted: 19 February 2020

Published: 12 March 2020

Citation:

Massolini BD, Contieri SSG, Lazarini GS, Bellacosa PA, Dobre M, Petroianu G, Brateanu A, Campos LA and Baltatu OC (2020) Therapeutic Renin Inhibition in Diabetic Nephropathy -A Review of the Physiological Evidence.

Front. Physiol. 11:190.

doi: 10.3389/fphys.2020.00190
The purpose of this systematic review was to investigate the scientific evidence to support the use of direct renin inhibitors (DRIs) in diabetic nephropathy (DN). MEDLINE was searched for articles reported until 2018. A standardized dataset was extracted from articles describing the effects of DRIs on plasma renin activity (PRA) in DN. A total of three clinical articles studying PRA as an outcome measure for DRls use in DN were identified. These clinical studies were randomized controlled trials (RCTs): one doubleblind crossover, one post hoc of a double-blind and placebo-controlled study, and one open-label and parallel-controlled study. Two studies reported a significant decrease of albuminuria associated with PRA reduction. One study had a DRI as monotherapy compared with placebo, and two studies had DRI as add-in to an angiotensin II (Ang II) receptor blocker (ARB). Of 10,393 patients with DN enrolled in five studies with DRI, 370 (3.6\%) patients had PRA measured. Only one preclinical study was identified that determined PRA when investigating the effects of aliskiren in DN. Moreover, most of observational preclinical and clinical studies identified report on a low PRA or hyporeninemic hypoaldosteronism in DM. Renin inhibition has been suggested for DN, but proof-of-concept studies for this are scant. A small number of clinical and preclinical studies assessed the PRA effects of DRIs in DN. For a more successful translational research for DRIs, specific patient population responsive to the treatment should be identified, and PRA may remain a biomarker of choice for patient stratification.

Keywords: diabetes mellitus, diabetic nephropathy, renin inhibitor, plasma renin activity, renin- angiotensin system

\section{INTRODUCTION}

Diabetic nephropathy $(\mathrm{DN})$ is the primary cause of chronic kidney disease. Despite therapeutic advances, DN remains the principal cause of mortality in diabetic patients (Dugbartey, 2017).

Renin-angiotensin system (RAS) has been classically involved in the progression of diabetic cardiovascular disease. A chronically activated endocrine or paracrine RAS is considered as a 
principal contributor to the pathophysiology of end-organ damage in diabetes mellitus (DM), including the DN (Urushihara and Kagami, 2017). As a result, therapeutic drugs for DN are targeting mostly the renin-angiotensin-aldosterone system (Yacoub and Campbell, 2015).

Although debate remains, the therapeutic drugs for DN currently consist mainly of angiotensin II (Ang II) receptor blockers (ARBs) and angiotensin-converting enzyme inhibitors (ACEIs) used for their antihypertensive and antiproteinuric measures (Bhattacharjee et al., 2016). Direct renin inhibitors (DRIs) acting on rate-limiting enzyme of the RAS offered probability of a greater inhibition of the system so as to have better therapeutic outcomes in patients with DN (Parving et al., 2008). The rationale for developing renin inhibitors was as follows: renin is the first and rate-limiting step in RAS cascade (low renin concentration in the pM range), renin has high specificity for angiotensinogen (little side effects anticipated), ACEIs and ARBs result in incomplete RAS suppression [reactive rise in plasma renin activity (PRA), "escape" mechanism, and other products of RAS (e.g., Ang1-7, AIII, and AIV)] (Wood and Close, 1996; Nussberger et al., 2002; Stanton, 2003). However, larger trials of the DRI aliskiren in combination with an ACE inhibitor or ARB in patients with DN did not reduce cardiovascular or renal outcomes (Parving et al., 2012).

Plasma renin activity played a central role as a pharmacological biomarker for drug development, safety, and dosing in the research and development (R\&D) of DRIs such as remikiren, enalkiren, zankiren, and aliskiren. Generally, DRIs induced rapid reductions of 65-95\% PRA (Lambers Heerspink et al., 2009). PRA has been used in the estimation of the extracellular volume, because this correlates inversely with PRA (Juncos, 2013). Hence, Brunner et al. (1972) categorized hypertensive patients by their volume status using PRA levels. Augmented PRA levels represent a risk factor of cardiovascular disease (Alderman et al., 1991; Parving et al., 2009). Whereas several pathologies are associated with an augmented PRA, DM and associated DN apparently are not.

The therapeutic effects of RAS inhibitors may be important depending on the pathological activation of endocrine and/or tissue RAS (Gasparo et al., 2013; de Alencar Franco Costa et al., 2015). For instance, disease conditions with low baseline PRA levels reduced the treatment efficacy of DRIs (Stanton et al., 2009). Few reviews on DRI for DN as therapeutic target discussed PRA as an outcome measure (Abassi et al., 2009; Rafiq et al., 2011; Jagadeesh et al., 2012). These reviews document that PRA is reduced in DM with or without DN.

Early studies described hyporeninemia or low-renin state as a characteristic state of circulatory RAS in DM patients with or without DN (Sousa et al., 2016). Our and other studies (de Alencar Franco Costa et al., 2015; Sousa et al., 2016) evidencing a diabetes-induced lowrenin status may indicate that a DRI is not always effective in treating DN. Therefore, the purpose of this study was to examine and synthesize the existing literature on DRI effects on PRA in DN. Literature search included studies that investigated DRIs such as remikiren, enalkiren, zankiren, or aliskiren in DN.

\section{METHODS}

\section{Literature Search Strategy}

We conducted a systematic review of investigative studies in accordance with the Preferred Reporting Items for Systematic Reviews and Meta-Analyses (PRISMA) consensus guidelines (Moher et al., 2016). A literature search of the MEDLINE database via PubMed was performed using a structured approach to identify relevant studies. A manual search was also conducted through searching the reference lists of relevant articles to expand the included studies. Eligibility assessment of identified articles was performed independently by two reviewers for preclinical studies and two reviewers for clinical studies, and inconsistencies were settled by one of the senior reviewers.

\section{Inclusion Criteria}

To identify relevant articles on original research, we associated terms referring to the use of PRA and/or renin inhibitors in DN. All experimental studies on humans and animals were eligible. Document types included were those produced as original and review papers written in English and published until 2018. The following Medical Subject Headings (MeSH) were used in the search: DN OR "diabetic kidney disease" AND "renin inhibitor" OR “aliskiren" OR "remikiren" OR "enalkiren" OR "zankiren." We used filters to select the type of study, and we gathered data from clinical trials and from case-control and cohort studies and reviews, designed to assess the effects of DRIs on PRA in DN.

\section{Exclusion Criteria}

Articles were excluded if they were clinical case reports, clinical case series, letters, editorials, opinions, points of views, or anecdotes. Also, articles that were written in languages other than English were discarded.

\section{Data Extraction and Quality Assessment}

Four investigators evaluated independently titles and abstracts and selected the articles for further full-text evaluation. Disagreements were resolved by consensus or by consultation with one of the senior investigators. When data were not found in the published article, authors were contacted to provide the missing information. The following data were collected: title, author and study group, publication year, DN, DRI, and PRA.

\section{RESULTS}

\section{Search Results and Study Selection}

Figure 1 details the search and selection process of articles that determined (or discussed in case of reviews) PRA when investigating DRI effects in DN. Of 920 potentially relevant 




FIGURE 1 | PRISMA Flow Diagram.

papers initially identified through the PubMed search, after deduplication, we reviewed 918 titles and abstracts; from these, we included 878 in a full-text review. A further 873 articles were excluded after full review, and five were included in the present study: one preclinical study and four clinical studies.

\section{Clinical Studies With Direct Renin Inhibitor in Diabetic Nephropathy That Determined Plasma Renin Activity}

Three clinical studies have been identified to have reported effects of DRI (aliskiren) on PRA in DN (Table 1). Two studies reported a significant decrease of albuminuria associated with PRA reduction (Persson et al., 2009; Abe et al., 2012). The post hoc analysis of ALTITUDE study (Parving et al., 2012) in a subset of 133 patients reported a non-significant reduction of urinary albumin creatinine of 22 and $9 \%$ in the aliskiren and placebo groups, respectively (Persson et al., 2012a).
One double-blind, randomized study that investigated the effect of aliskiren as monotherapy in patients with DM and hypertension (HTN) reported a decrease of $72 \%$ in PRA (Persson et al., 2009). Two other studies that investigated aliskiren or placebo in addition to an ARB [one a post hoc analysis (Persson et al., 2012a) and the other an open-label, randomized study (Abe et al., 2012)] reported a PRA decrease of 71-77\%. The data from the studies were heterogeneous and not sufficient to carry out a quantitative analysis. There were not enough data in two studies (Abe et al., 2012; Persson et al., 2012a), the reported PRA data had a skewed distribution in one study (Persson et al., 2009), and there was no blindness in one study (Abe et al., 2012). In addition, in one study, PRA was determined only in a subset of patients from the total investigated in the aliskiren group: 22\% (133 of 599) patients in the (Persson et al., 2012a) study.

Of 10,393 patients with DN enrolled in five studies [599 in Parving et al. (2008); 26 in Persson et al. (2009); 8,561 in the ALTITUDE study (Parving et al., 2012); 64 in Abe et al. (2012); 
TABLE 1 | Clinical Studies with DRI in diabetic nephropathy that determined plasma renin activity.

\begin{tabular}{|c|c|c|c|c|c|}
\hline Study & Study type & $\begin{array}{l}\text { DRI monotherapy/add-in } \\
\text { therapy }\end{array}$ & Study participants & Renal outcomes & DRI effect on PRA \\
\hline $\begin{array}{l}\text { Persson et al., } \\
2009\end{array}$ & $\begin{array}{l}\text { Double-blind, } \\
\text { randomized, crossover } \\
\text { trial }\end{array}$ & $\begin{array}{l}\text { Aliskiren, irbesartan, and } \\
\text { aliskiren/irbesartan, } \\
\text { 2-month treatment }\end{array}$ & $\begin{array}{l}26 \text { patients with T2DM, } \\
\text { HTN, and albuminuria } \\
\text { (>100 mg/day) }\end{array}$ & $\begin{array}{l}\text { Significant reduction in } \\
\text { urinary albumin, } \\
\text { glomerular filtration } \\
\text { rate, and } 24-h \text { blood } \\
\text { pressure from placebo }\end{array}$ & $\begin{array}{l}72 \% \downarrow \text { as monotherapy } \\
\text { compared with placebo }\end{array}$ \\
\hline $\begin{array}{l}\text { Persson et al., } \\
2012 a\end{array}$ & $\begin{array}{l}\text { AVOID post hoc } \\
\text { analysis }\end{array}$ & $\begin{array}{l}\text { Add-in: aliskiren or placebo } \\
\text { in addition to losartan, } \\
6 \text {-month treatment }\end{array}$ & $\begin{array}{l}\text { Patients with HTN and } \\
\text { T2DM with } \\
\text { nephropathy: a } \\
\text { prespecified subset of } \\
133(22 \%) \text { patients } \\
\text { from a total of } 599 \\
\text { patients }\end{array}$ & $\begin{array}{l}\text { Not significant } \\
\text { reduction in urinary } \\
\text { albumin-creatinine ratio }\end{array}$ & $\begin{array}{l}71 \% \downarrow \text { compared with } \\
\text { placebo (90\% } \downarrow \text { compared } \\
\text { with baseline; placebo: } \\
19 \% \downarrow)\end{array}$ \\
\hline Abe et al., 2012 & $\begin{array}{l}\text { Open-label, } \\
\text { randomized, } \\
\text { parallel-controlled study }\end{array}$ & $\begin{array}{l}\text { Add-in: aliskiren or placebo } \\
\text { in addition to telmisartan } \\
\text { and amlodipine, 6-month } \\
\text { treatment }\end{array}$ & $\begin{array}{l}64 \text { patients with T2DM, } \\
\text { DN, and HTN }\end{array}$ & $\begin{array}{l}\text { Significant reduction in } \\
\text { urinary } \\
\text { albumin-creatinine ratio }\end{array}$ & $\begin{array}{l}70-77 \% \downarrow \text { compared with } \\
\text { baseline; } 89 \% \downarrow \text { compared } \\
\text { with calcium channel } \\
\text { blocker (CCB) group }\end{array}$ \\
\hline
\end{tabular}

T2DM, type 2 diabetes mellitus; DN, diabetic nephropathy; HTN, hypertension; PRA, plasma renin activity; DRI, direct renin inhibitor.

1,143 in the VIvID study (Bakris et al., 2013)], 370 (3.6\%) patients had PRA measured (Persson et al., 2009, 2012a; Abe et al., 2012).

\section{Preclinical Studies With Direct Renin Inhibitor in Diabetic Nephropathy That Determined Plasma Renin Activity}

One preclinical proof-of-concept study testing the effects of aliskiren in DN determined PRA (Table 2). This study used as model for DM the streptozotocin (STZ)-induced DM in C57BL/6J mice fed on a high-fat diet, determined PRA, and found higher levels in DN when compared with the control nonDN (Kidokoro et al., 2016). In Table 2 are included articles that reported renal renin outcome measures, including plasma renin concentration and renin mRNA expression.

\section{DISCUSSION}

The present study shows that a low number of preclinical and clinical studies with DRIs as monotherapy or add-in therapy in DN assessed PRA. Only two randomized controlled

TABLE 2 | Preclinical studies with DRI in diabetic nephropathy that determined plasma renin or renal RAS.

\begin{tabular}{|c|c|c|c|c|c|}
\hline Study & Experimental model & DRI & Outcome & $\begin{array}{l}\text { Renal/plasma renin in } \\
\text { DN control vs. healthy } \\
\text { control }\end{array}$ & $\begin{array}{l}\text { Effects of DRI on } \\
\text { renal/plasma renin }\end{array}$ \\
\hline Dong et al., 2010a & $\begin{array}{l}\mathrm{db} / \mathrm{db} \text { mice, with } \\
\text { obesity and T2DM }\end{array}$ & $\begin{array}{l}\text { Aliskiren, } 6 \text { weeks' } \\
\text { treatment }\end{array}$ & $\begin{array}{l}\text { Protects against } \\
\text { cardiovascular } \\
\text { complications and } \\
\text { pancreatic injury }\end{array}$ & $\begin{array}{l}\text { Renal renin mRNA not } \\
\text { different than that of } \\
\text { control } \mathrm{db} / \mathrm{m} \text { mice }\end{array}$ & $\begin{array}{l}\text { Increased renal renin } \\
\text { mRNA expression }\end{array}$ \\
\hline Dong et al., 2010b & $\begin{array}{l}\mathrm{db} / \mathrm{db} \text { mice with } \\
\text { obesity and T2DM }\end{array}$ & $\begin{array}{l}\text { Aliskiren, } 6 \text { weeks' } \\
\text { treatment }\end{array}$ & Protects against DN & $\begin{array}{l}\text { Renal renin mRNA higher } \\
\text { than that in control } \mathrm{db} / \mathrm{m} \\
\text { mice }\end{array}$ & $\begin{array}{l}\text { Increased renal renin } \\
\text { mRNA expression }\end{array}$ \\
\hline Kang et al., 2011 & $\begin{array}{l}\mathrm{db} / \mathrm{db} \text { mice with } \\
\text { obesity and T2DM }\end{array}$ & $\begin{array}{l}\text { Aliskiren, } 3 \text { months' } \\
\text { treatment }\end{array}$ & $\begin{array}{l}\text { Decreased albuminuria, } \\
\text { glomerulosclerosis, } \\
\text { interstitial fibrosis, improved } \\
\text { insulin resistance }\end{array}$ & $\begin{array}{l}\text { Lower plasma renin } \\
\text { concentration }(\mathrm{PRC}) \text { in } \\
\mathrm{db} / \mathrm{db} \text { mice than in } \mathrm{db} / \mathrm{m} \\
\text { mice (control non-DM) }\end{array}$ & Increased PRC \\
\hline Wang et al., 2014 & $\begin{array}{l}\text { STZ-DBA/2J mice fed } \\
\text { on a high-fat diet }\end{array}$ & $\begin{array}{l}\text { Aliskiren, } 6 \text { weeks' } \\
\text { treatment }\end{array}$ & Protects against DN & $\begin{array}{l}\text { Renal renin mRNA in DN } \\
\text { higher than that in control } \\
\text { non-DN }\end{array}$ & $\begin{array}{l}\text { Increased renal renin } \\
\text { mRNA expression }\end{array}$ \\
\hline Zhou et al., 2015 & $\begin{array}{l}\mathrm{db} / \mathrm{db} \text { mice, with } \\
\text { obesity and } \\
\text { T2DM + uninephrectomy }\end{array}$ & $\begin{array}{l}\text { Aliskiren, } 4 \text { weeks' } \\
\text { treatment }\end{array}$ & Protects against DN & $\begin{array}{l}\text { PRC normal, renal renin } \\
\text { mRNA higher than that in } \\
\text { control non-DN }\end{array}$ & $\begin{array}{l}\text { Increased PRC and } \\
\text { renal renin mRNA } \\
\text { expression }\end{array}$ \\
\hline Kidokoro et al., 2016 & $\begin{array}{l}\text { STZ-C57BL/6J mice } \\
\text { fed on a high-fat diet }\end{array}$ & $\begin{array}{l}\text { Aliskiren, } 4 \text { weeks' } \\
\text { treatment }\end{array}$ & Protects against DN & $\begin{array}{l}\text { PRA and in vivo imaging } \\
\text { of renal renin activity } \\
\text { higher than that in control } \\
\text { non-DN }\end{array}$ & $\begin{array}{l}\text { Decreased PRA and } \\
\text { in vivo imaging of renal } \\
\text { renin activity }\end{array}$ \\
\hline
\end{tabular}

T2DM, type 2 diabetes mellitus; $D R I$, direct renin inhibitor; RAS, renin-angiotensin system; $D N$, diabetic nephropathy. 
studies reported renoprotective effects in DN associated with a significant reduction in PRA.

Of eight publications identified to report DRI effects on urinary albumin in DN (Parving et al., 2008, 2012; Persson et al., 2009, 2010, 2011, 2012a,b; Abe et al., 2012), only three clinical studies presented data on PRA. All three involved patients with both DM and HTN. As aliskiren does not lower blood pressure in hypertensive patients with low PRA (Sealey and Laragh, 2009), Jagadeesh et al. (2012) suggested that "it may be useful to dichotomize RAAS-related pathologic syndromes into ones associated with high renin (some HTN, any HTN after diuretic treatment), where aliskiren appears to be quite effective, and low-renin" (like diabetes), where aliskiren is of uncertain value. Indeed, in the AVOID study (Parving et al., 2008), a prespecified subset of 133 (22\%) patients from a total of 599 patients was identified with a significant decrease in PRA by aliskiren (Persson et al., 2012a). The study of Uresin et al. (2007) that reported a significant reduction in 24-h ambulatory blood pressure presented PRA data on $32 \%$ of the total patients recruited in the DRI study group. As such, important information that could lead to patient stratification could be learned from disclosing the PRA data from the ALTITUDE study (Parving et al., 2012).

Dual therapy of the DRI aliskiren with ACEI or ARBs was commonly investigated in patients with HTN, heart failure, and diabetes with or without proteinuria. It is conceptualized that the antihypertensive efficacy of aliskiren is increased when adding ACEIs, ARBs, or diuretics, which produce a reactive increase in PRA. Indeed, aliskiren in combination with ACEIs or ARBs showed significant blood pressure and proteinuria reductions than monotherapy alone in phase II trials with hypertensive patients with or without DM (Persson et al., 2009), reviewed by Şen et al. (2013). Clinical trials that studied the combination of aliskiren and ACEI or ARBs and involved patients with DM include Pool 2007, ALOFT 2008, ALLAY 2009, AVANTE GARDE 2010, VANTAGE 2010, and ASPIRE 2011. These studies were systematically reviewed by Harel et al. (2012). They were not designed to investigate outcomes in DM patients. A metaanalysis of 13,395 patients with diabetes showed no benefit from the addition of aliskiren to standard medical therapy (Zheng et al., 2017).

Finding a preclinical experimental model for DM and DN was challenged by the high selectivity of aliskiren for human renin compared with renin from other species (IC50 values [50\% inhibitory concentrations]: human 0.6 , marmoset 2 , rat 80, dog 7) (Wood et al., 2003). The first studies of DRI on an experimental DM model used the STZ-induced DM in highrenin hypertensive (mRen-2)27 rats (Kelly et al., 2007; Feldman et al., 2008). However, this DM model cannot consider the phenotype alterations as primarily induced by DM because these rats genetically activated renin production. Four studies reported DRI effects on $\mathrm{DN}$ of $\mathrm{db} / \mathrm{db}$ mice (Table 2). Another study on $\mathrm{db} / \mathrm{db}$ mice showed no significant differences in their PRA compared to control db/m mice (Gallo et al., 2016).

Experimental models investigated for proof-of-concept efficacy of aliskiren in $\mathrm{DN}$ were $\mathrm{db} / \mathrm{db}$ mice for type $2 \mathrm{DM}$ (T2DM) and STZ mice (DBA/2J and C57BL/6J strains) for type 1 DM (T1DM). The $\mathrm{db} / \mathrm{db}$ mice are characterized by T2DM,
TABLE 3A | Preclinical studies that determined PRA in experimental DM.

\begin{tabular}{|c|c|c|}
\hline Study & Experimental model & DM effect on PRA \\
\hline Christlieb, 1974 & $\begin{array}{l}\text { Alloxan-DM rat, acute DM } \\
\text { (alloxan is nephrotoxic) }\end{array}$ & Low PRA \\
\hline Christlieb et al., 1979 & Alloxan-DM rat, 3 months & $\begin{array}{l}\text { PRA decreased } \\
\text { progressively }\end{array}$ \\
\hline $\begin{array}{l}\text { Ballermann et al., } \\
1984\end{array}$ & STZ-DM rat, 1 month & $\begin{array}{l}\text { PRC values in } \\
\text { untreated DM rats were } \\
\text { lower than those of } \\
\text { insulin-treated rats or } \\
\text { controls }\end{array}$ \\
\hline Pratt et al., 1985 & Alloxan-DM rat, 7 weeks & Low PRA \\
\hline Kigoshi et al., 1986 & STZ-DM rat, 1.5 months & $\begin{array}{l}\text { Hyporeninemic } \\
\text { hypoaldosteronism }\end{array}$ \\
\hline Kim, 1994 & STZ-DM rat, 2 months & $\begin{array}{l}\text { Hyporeninemic } \\
\text { hypoaldosteronism }\end{array}$ \\
\hline Di Loreto et al., 2004 & Alloxan-DM rat, 1 month & $\begin{array}{l}\text { Low PRA, glucose } \\
\text { overload did not } \\
\text { significantly affect these } \\
\text { values }\end{array}$ \\
\hline $\begin{array}{l}\text { de Alencar Franco } \\
\text { Costa et al., } 2015\end{array}$ & STZ-DM rat, 3 months & $\begin{array}{l}\text { Low PRA, PRC, and } \\
\text { renal renin mRNA }\end{array}$ \\
\hline
\end{tabular}

PRA, plasma renin activity; DN, diabetic nephropathy; DM, diabetes mellitus; STZ, streptozotocin.

elevated systolic blood pressure, obesity, and hyperlipidemia. They develop T2DM with high plasma levels of insulin and glucose at weeks 9-10 of age (Forbes and Cooper, 2013). The main outcomes studied for $\mathrm{DN}$, including increased albumin excretion and glomerular pathology, are very similar between mouse lines with T1DM or T2DM and humans with DM (Azushima et al., 2017).

Locally activated synthesis and activity of renin have been identified in kidney and other organs in different pathologies (Bader et al., 2001). Such organs where a local tissue RAS has been postulated include the heart, blood vessels, kidney, brain, adipose tissue, adrenal gland, pancreas, liver, reproductive system, lymphatic tissue, placenta, and eyes (Nehme et al., 2019). Diseases where chronically activated local tissue RAS has been identified include HTN, atherosclerosis, heart failure, cardiac hypertrophy and fibrosis, chronic kidney disease, and glaucoma (Ames et al., 2019; Nehme et al., 2019). An increase in local production of active angiotensins could be through the classical renin-ACE pathway or through alternative pathways (Ferrario et al., 2014). Translational proof-of-concept studies shall distinguish the enzymes involved in these RAS pathways in order to identify therapeutic targets. For instance, we have demonstrated in a proof-of-concept study that renin might be a therapeutic target in glaucoma (Wang et al., 2012). This does not seem to be the case in DN where both preclinical and clinical proof-of-concept studies indicate that $\mathrm{DN}$ is associated with a low-renin state. In Table 3B, we summarized the clinical studies that described hyporeninemia in DM, with the first report dated year 1973. These studies indicate that hyporeninemic hypoaldosteronism is underdiagnosed in DM (Sousa et al., 2016). Several mechanisms have been suggested as responsible for the reduction in renin release in patients with DM, including 
TABLE 3B | Clinical studies on low PRA in DN.

\begin{tabular}{|c|c|c|}
\hline Study & Study participants & PRA in DM \\
\hline Chelaghma and Oyibo, 2018 & One patient with DM & Hyporeninemic hypoaldosteronism \\
\hline deLeiva et al., 2010 & Two patients with DM & Hypoaldosteronism due to low PRA \\
\hline Hollenberg et al., 2003 & 31 Patients with T1DM & Intrarenal RAS activated without PRA \\
\hline Bojestig et al., 2000 & 80 Patients with T1DM & Low PRA and high plasma ANP \\
\hline Elisaf et al., 1999 & One patient with DM & Hyporeninemic, hypoaldosteronism, and autonomic neuropathy \\
\hline Bonnet and Thivolet, 1996 & One patient with DM & Hyporeninemic hypoaldosteronism \\
\hline Fukuchi, 1991 & 118 Patients with DM & $\begin{array}{l}\text { Hyporeninemic selective hypoaldosteronism may be associated with } \\
\text { DM nephropathy or DM neuropathy }\end{array}$ \\
\hline Paulsen et al., 1989 & 100 Teenage patients with T1DM & Decline of PRA over 5 years \\
\hline Villoria et al., 1988 & 13 Patients with DM and chronic renal failure & $\begin{array}{l}\text { Hyporeninemic hypoaldosteronism associated with type IV renal tubular } \\
\text { acidosis }\end{array}$ \\
\hline Antonipillai et al., 1981 & 12 Patients with DM & Low PRA and active renin (AR) \\
\hline Fernandez-Cruz et al., 1979 & 16 Normotensive diabetics with long-term disease & Hyporeninemia \\
\hline Farese et al., 1980 & Four patients with DM & Diabetic hyporeninemic hypoaldosteronism \\
\hline Tuck et al., 1979 & Five patients with DM with mild renal insufficiency & $\begin{array}{l}\text { Hyporeninemic hypoaldosteronism associated with DM and neuropathy } \\
\text { may be due to decreased sympathetic nervous system activity }\end{array}$ \\
\hline Kuhlmann et al., 1978 & Three patients with DM & Hyporeninemic hypoaldosteronism \\
\hline Christlieb et al., 1978 & 44 Patients with DM & $\begin{array}{l}\text { Hyporeninemic hypoaldosteronism is frequent in diabetics with } \\
\text { nephropathy }\end{array}$ \\
\hline Christlieb et al., 1976 & 48 Patients with DM & $\begin{array}{l}\text { (1) PRA is normal in normotensive diabetics (2) Patients with diabetes, } \\
\text { hypertension, and nephropathy have "low renin hypertension" }\end{array}$ \\
\hline Christlieb et al., 1974 & Eight patients with DM & Low PRA \\
\hline de Chatel et al., 1977 & 60 Patients with DM & Low PRA \\
\hline Perez et al., 1977 & 12 Patients with DM & Hyporeninemia and hypoaldosteronism \\
\hline Weidmann et al., 1973 & Four patients with DM & Low PRA \\
\hline
\end{tabular}

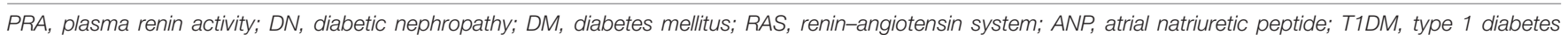
mellitus.

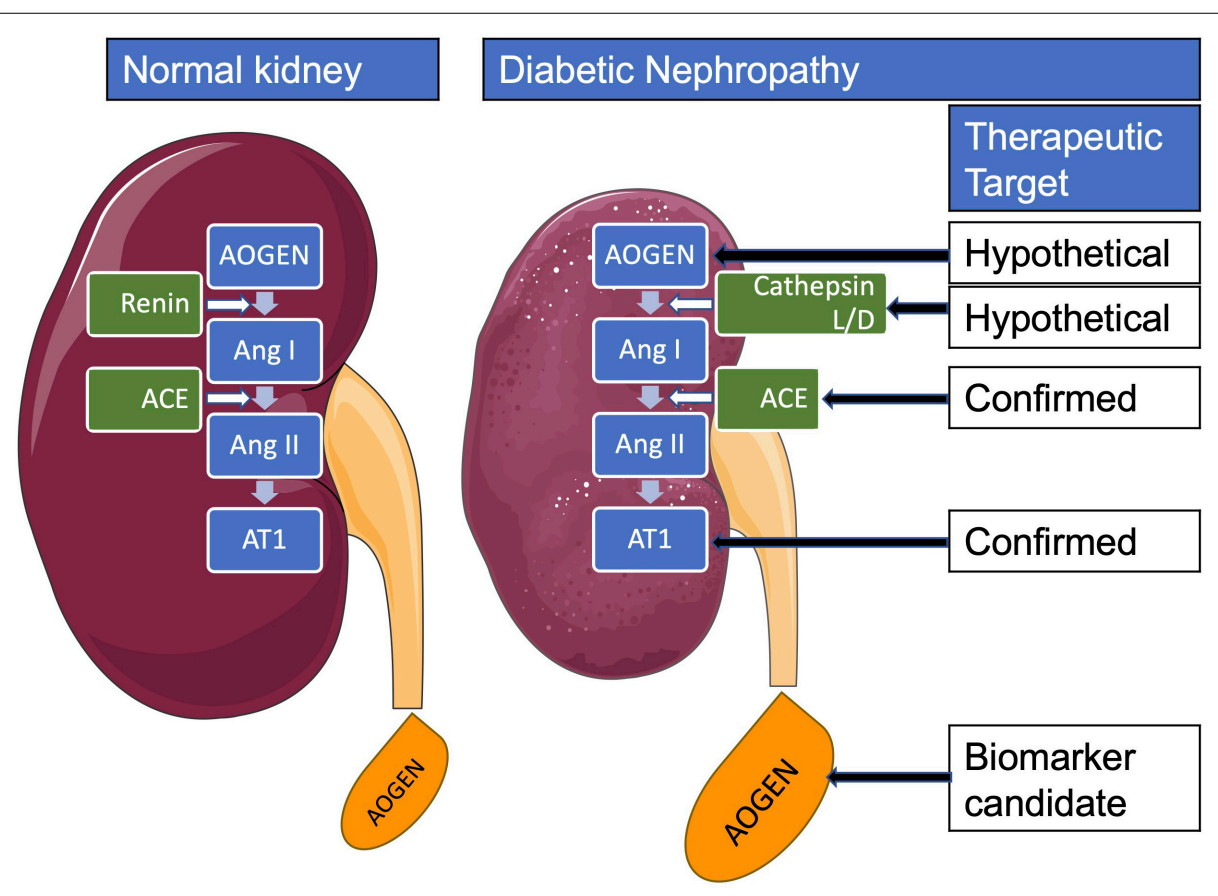

FIGURE 2 | Renal renin-angiotensin system in diabetes mellitus. AOGEN, angiotensinogen; ACE, angiotensin-converting enzyme; Ang, angiotensin; AT1, angiotensin type 1 receptor. 
juxtaglomerular injury, autonomic dysfunction, and primary increase in renal salt retention with volume expansion (Phelps et al., 1980; Sousa et al., 2016). The first experimental studies of RAS in DM used alloxan-DM or STZ-DM rat models (Table 3A). Preclinical evidence for an activated renal RAS in DM is suggested by our and others studies on increased synthesis and urinary secretion of renal angiotensinogen (Zimpelmann et al., 2000; Saito et al., 2009; de Alencar Franco Costa et al., 2015; Lee et al., 2017) (Figure 2 shows urinary angiotensinogen as a potential biomarker). STZ-induced DM in rats caused a $69 \%$ increase of Ang II in the renal interstitial fluid, which was decreased $27 \%$ by aliskiren (6 weeks' treatment) (Matavelli et al., 2012). As aliskiren did not normalize the DM-increased renal interstitial fluid Ang II, alternative Ang II-forming pathways might have been activated. One candidate enzyme that may take over the renin activity in kidney to activate the local Ang II production is cathepsin L. Cathepsin L was identified as a potential sex-specific biomarker for renal damage by the Actelion group (Bauer et al., 2011). Cathepsin L appears to be importantly involved in the development of albuminuria and renal damage in early experimental DN (Garsen et al., 2016) (Figure 2). Angiotensinogen may be degraded by cathepsins including cathepsin L, which may degrade angiotensinogen (Watanabe et al., 1989). As cathepsin L can be involved in the pathogenesis of DN through several mechanisms, targeting with suitable antagonists may hold promises for therapeutic interventions (Kumar and Anders, 2016). PRA is not a good indicator of local RAS activity as measure circulating production of angiotensin I, where ACE, alternative Ang II-forming enzymes, and Ang II might be increased in the local tissue. Although PRA is a pharmacological efficacy biomarker for aliskiren and has been considered as an outcome measure in DM, the effects of renin inhibitors on local tissue RAS are not easily demonstrable

\section{REFERENCES}

Abassi, Z., Winaver, J., and Feuerstein, G. Z. (2009). The biochemical pharmacology of renin inhibitors: implications for translational medicine in hypertension, diabetic nephropathy and heart failure: expectations and reality. Biochem. Pharmacol. 78, 933-940. doi: 10.1016/j.bcp.2009.05.018

Abe, M., Maruyama, N., Suzuki, H., Fujii, Y., Ito, M., Yoshida, Y., et al. (2012). Additive renoprotective effects of aliskiren on angiotensin receptor blocker and calcium channel blocker treatments for type 2 diabetic patients with albuminuria. Hypertens. Res. 35, 874-881. doi: 10.1038/hr.2012.45

Alderman, M. H., Madhavan, S., Ooi, W. L., Cohen, H., Sealey, J. E., and Laragh, J. H. (1991). Association of the renin-sodium profile with the risk of myocardial infarction in patients with hypertension. N. Engl. J. Med. 324, 1098-1104. doi: 10.1056/NEJM199104183241605

Ames, M. K., Atkins, C. E., and Pitt, B. (2019). The renin-angiotensin-aldosterone system and its suppression. J. Vet. Intern. Med. 33, 363-382. doi: 10.1111/jvim. 15454

Antonipillai, I., Tan, S. Y., Suzuki, S., Franco-Saenz, R., and Mulrow, P. J. (1981). Active and inactive renin in low renin states: studies in human plasma. J. Clin. Endocrinol. Metab. 53, 694-697. doi: 10.1210/jcem-534-694

Azushima, K., Gurley, S. B., and Coffman, T. M. (2017). Modelling diabetic nephropathy in mice. Nat. Rev. Nephrol. 14, 48-56. doi: 10.1038/nrneph. 2017.142

Bader, M., Peters, J., Baltatu, O., Müller, D. N., Luft, F. C., and Ganten, D. (2001). Tissue renin-angiotensin systems: new insights from experimental in clinical studies because there are no available biomarkers for local RAS activation. Studies on urinary peptidome might lead to the characterization of biomarkers for local renal RAS activation, such as cathepsin L or D (Krochmal et al., 2017).

\section{CONCLUSION}

Very few studies addressed the PRA as the outcome measure of DRI treatment effect in DN. Therefore, for a more successful translational research, specific patient population where DRI treatment is effective in DN should be identified. Additional well-designed randomized controlled trials (RCTs) using PRA as a marker for patient stratification and randomization may be warranted.

\section{AUTHOR CONTRIBUTIONS}

$\mathrm{OB}$ and $\mathrm{LC}$ contributed to the conception and design of the study. $\mathrm{MD}, \mathrm{AB}, \mathrm{GP}, \mathrm{OB}$, and $\mathrm{LC}$ analyzed and interpreted the data. MD, $\mathrm{AB}, \mathrm{GP}, \mathrm{OB}$, and LC drafted the manuscript. All authors provided critical revision of the article.

\section{FUNDING}

$\mathrm{BM}, \mathrm{SC}, \mathrm{GL}$, and $\mathrm{PB}$ received institutional fellowship for this study. OB is supported by the National Council for Scientific and Technological Development (CNPq, 307760/2018-9). This publication is based upon work supported by the Khalifa University of Science and Technology under Award No. FSU2020-33 to OB.

animal models in hypertension research. J. Mol. Med. 79, 76-102. doi: 10.1007/ s001090100210

Bakris, G. L., Oparil, S., Purkayastha, D., Yadao, A. M., Alessi, T., and Sowers, J. R. (2013). Randomized study of antihypertensive efficacy and safety of combination aliskiren/valsartan vs valsartan monotherapy in hypertensive participants with type 2 diabetes mellitus. J. Clin. Hypertens. 15, 92-100. doi: $10.1111 /$ jch. 12032

Ballermann, B. J., Skorecki, K. L., and Brenner, B. M. (1984). Reduced glomerular angiotensin II receptor density in early untreated diabetes mellitus in the rat. Am. J. Physiol. 247, F110-F116. doi: 10.1152/ajprenal.1984.247.1.F110

Bauer, Y., Hess, P., Qiu, C., Klenk, A., Renault, B., Wanner, D., et al. (2011). Identification of Cathepsin L as a Potential Sex-Specific Biomarker for Renal Damage. Hypertension 57, 795-801. doi: 10.1161/HYPERTENSIONAHA.110. 157206

Bhattacharjee, N., Barma, S., Konwar, N., Dewanjee, S., and Manna, P. (2016). Mechanistic insight of diabetic nephropathy and its pharmacotherapeutic targets: an update. Eur. J. Pharmacol. 791, 8-24. doi: 10.1016/j.ejphar.2016. 08.022

Bojestig, M., Nystrom, F. H., Arnqvist, H. J., Ludvigsson, J., and Karlberg, B. E. (2000). The renin-angiotensin-aldosterone system is suppressed in adults with Type 1 diabetes. JRAAS J. Renin Angiotensin Aldoster. Syst. 1, 353-356. doi: 10.3317/jraas.2000.065

Bonnet, F., and Thivolet, C. H. (1996). Reversible hyperkalemia at the initiation of ACE inhibitors in a young diabetic patient with latent hyporeninemic hyporeninemic hypoaldosteronism. Diabetes Care 19, 781. doi: 10.2337/diacare. 19.7.781a 
Brunner, H. R., Laragh, J. H., Baer, L., Newton, M. A., Goodwin, F. T., Krakoff, L. R., et al. (1972). Essential hypertension: renin and aldosterone, heart attack and stroke. N. Engl. J. Med. 286, 441-449. doi: 10.1056/NEJM197203022860901

Chelaghma, N., and Oyibo, S. O. (2018). Hyporeninemic hypoaldosteronism in a patient with diabetes mellitus: an unforgettable case report. Int. Med. Case Rep. J. 11, 69-72. doi: 10.2147/IMCRJ.S158628

Christlieb, A. R. (1974). Renin, angiotensin, and norepinephrine in alloxan diabetes. Diabetes 23, 962-970. doi: 10.2337/diab.23.12.962

Christlieb, A. R., Kaldany, A., and D'Elia, J. A. (1976). Plasma renin activity and hypertension in diabetes mellitus. Diabetes 25, 969-974. doi: 10.2337/diab.25. 10.969

Christlieb, A. R., Kaldany, A., D’Elia, J. A., and Williams, G. H. (1978). Aldosterone responsiveness in patients with diabetes mellitus. Diabetes 27, 732-737. doi: 10.2337/diab.27.7.732

Christlieb, A. R., Long, R., and Underwood, R. H. (1979). Renin-angiotensinaldosterone system, electrolyte homeostasis and blood pressure in alloxan diabetes. Am. J. Med. Sci. 277, 295-303. doi: 10.1097/00000441-19790500000008

Christlieb, A. R., Munichoodappa, C., and Braaten, J. T. (1974). Decreased response of plasma renin activity to orthostasis in diabetic patients with orthostatic hypotension. Diabetes 23, 835-840. doi: 10.2337/diab.23.10.835

de Alencar Franco Costa, D., Todiras, M., Campos, L. A. A., Cipolla-Neto, J., Bader, M., and Baltatu, O. C. C. (2015). Sex-dependent differences in renal angiotensinogen as an early marker of diabetic nephropathy. Acta Physiol. 213, 740-746. doi: 10.1111/apha.12441

de Chatel, R., Weidmann, P., Flammer, J., Ziegler, W. H., Beretta-Piccoli, C., Vetter, W., et al. (1977). Sodium, renin, aldosterone, catecholamines, and blood pressure in diabetes mellitus. Kidney Int. 12, 412-421. doi: 10.1038/ki.1977.132

deLeiva, A., Zager, P. G., Melby, J. C., Christlieb, A. R., Graham, C. A., Luetscher, J. A., et al. (2010). Big renin and biosynthetic defect of aldosterone in diabetes mellitus. N. Engl. J. Med. 295, 639-643. doi: 10.1056/nejm197609162951203

Di Loreto, V., Moreno, H. S., Puche, R. C., and Locatto, M. E. (2004). Severe hyperglycemia: a determinant factor for hypofiltration in alloxan diabetic rats. Acta Diabetol. 41, 56-62. doi: 10.1007/s00592-004-0145-z

Dong, Y. F., Liu, L., Kataoka, K., Nakamura, T., Fukuda, M., Tokutomi, Y., et al. (2010a). Aliskiren prevents cardiovascular complications and pancreatic injury in a mouse model of obesity and type 2 diabetes. Diabetologia 53, 180-191. doi: 10.1007/s00125-009-1575-1575

Dong, Y. F., Liu, L., Lai, Z. F., Yamamoto, E., Kataoka, K., Nakamura, T., et al. (2010b). Aliskiren enhances protective effects of valsartan against type 2 diabetic nephropathy in mice. J. Hypertens. 28, 1554-1565. doi: 10.1097/HJH. 0b013e328338bb11

Dugbartey, G. J. (2017). Diabetic nephropathy: a potential savior with 'rotten-egg' smell. Pharmacol Rep. 69, 331-339. doi: 10.1016/j.pharep.2016.11.004

Elisaf, M. S., Tomos, P. P., Milionis, H. J., and Siamopoulos, K. C. (1999). Prerenal azotemia in a diabetic patient with hyporeninemic hypoaldosteronism and autonomic neuropathy. Diabetes Metab. 25, 344-346.

Farese, R. V., Rodriguez-Colomé, M., and O’Malley, B. C. (1980). Urinary prostaglandins following frusemide treatment and salt depletion in normal subjects and subjects with diabetic hyporeninaemic hypoaldosteronism. Clin. Endocrinol. 13, 447-453. doi: 10.1111/j.1365-2265.1980.tb03410.x

Feldman, D. L., Jin, L., Xuan, H., Contrepas, A., Zhou, Y., Webb, R. L., et al. (2008). Effects of aliskiren on blood pressure, albuminuria, and (Pro)renin receptor expression in diabetic TG(mRen-2)27 Rats. Hypertension 52, 130-136. doi: 10.1161/HYPERTENSIONAHA.107.108845

Fernandez-Cruz, A., Noth, R. H., Lassman, M. N., Hollis, J. B., and Mulrow, P. J. (1979). Low plasma renin activity in normotensive patients with diabetes mellitus: relationship to neuropathy. Hypertens 3, 87-92. doi: 10.1161/01.hyp. 3.1 .87

Ferrario, C. M., Ahmad, S., Nagata, S., Simington, S. W., Varagic, J., Kon, N., et al. (2014). An evolving story of angiotensin-II-forming pathways in rodents and humans. Clin. Sci. 126, 461-469. doi: 10.1042/CS20130400

Forbes, J. M., and Cooper, M. E. (2013). Mechanisms of diabetic complications. Physiol. Rev. 93, 137-188. doi: 10.1152/physrev.00045.2011

Fukuchi, S. (1991). Studies on the cause and the treatment of hyporeninemic selected hypoaldosteronism in diabetic nephropathy. Jpn. J. Med. 30, 617-618.

Gallo, L. A., Ward, M. S., Fotheringham, A. K., Zhuang, A., Borg, D. J., Flemming, N. B., et al. (2016). Once daily administration of the SGLT2 inhibitor, empagliflozin, attenuates markers of renal fibrosis without improving albuminuria in diabetic db/db mice. Sci. Rep. 6:26428. doi: 10.1038/srep26428

Garsen, M., Rops, A. L., Dijkman, H., Willemsen, B., van Kuppevelt, T. H., Russel, F. G., et al. (2016). Cathepsin L is crucial for the development of early experimental diabetic nephropathy. Kidney Int. 90, 1012-1022. doi: 10.1016/j. kint.2016.06.035

Gasparo, M. D., Speth, R. C., Baltatu, O. C., and Vanderheyden, P. (2013). Brain RAS: hypertension and beyond. Int. J. Hypertens. 2013:157180. doi: 10.1155/ 2013/157180

Harel, Z., Gilbert, C., Wald, R., Bell, C., Perl, J., Juurlink, D., et al. (2012). The effect of combination treatment with aliskiren and blockers of the renin-angiotensin system on hyperkalaemia and acute kidney injury: systematic review and meta-analysis. BMJ 344:e42. doi: 10.1136/bmj.e42

Hollenberg, N. K., Price, D. A., Fisher, N. D. L., Lansang, M. C., Perkins, B., Gordon, M. S., et al. (2003). Glomerular hemodynamics and the reninangiotensin system in patients with type 1 diabetes mellitus. Kidney Int. 63, 172-178. doi: 10.1046/j.1523-1755.2003.00701.x

Jagadeesh, G., Balakumar, P., and Stockbridge, N. (2012). How well do aliskiren's purported mechanisms track its effects on cardiovascular and renal disorders? Cell. Signal. 24, 1583-1591. doi: 10.1016/j.cellsig.2012.04.003

Juncos, L. (2013). Direct renin inhibition: extricating facts from façades. Ther. Adv. Cardiovasc. Dis. 7, 153-167. doi: 10.1177/1753944713479995

Kang, Y. S., Lee, M. H., Song, H. K., Hyun, Y. Y., Cha, J. J., Ko, G. J., et al. (2011). Aliskiren improves insulin resistance and ameliorates diabetic vascular complications in db/db mice. Nephrol. Dial. Transplant. 26, 1194-1204. doi: 10.1093/ndt/gfq579

Kelly, D. J., Zhang, Y., Moe, G., Naik, G., and Gilbert, R. E. (2007). Aliskiren, a novel renin inhibitor, is renoprotective in a model of advanced diabetic nephropathy in rats. Diabetologia 50, 2398-2404. doi: 10.1007/s00125-007-0795-799

Kidokoro, K., Satoh, M., Itano, S., Kuwabara, A., Sasaki, T., and Kashihara, N. (2016). Feasibility of fluorescence energy transfer system for imaging the renoprotective effects of aliskiren in diabetic mice. JRAAS J. Renin Angiotensin Aldoster. Syst. 17, 1-8. doi: 10.1177/1470320315625704

Kigoshi, T., Imaizumi, N., Azukizawa, S., Yamamoto, I., Uchida, K., Konishi, F., et al. (1986). Effects of angiotensin II, adrenocorticotropin, and potassium on aldosterone production in adrenal zona glomerulosa cells from streptozotocininduced diabetic rats. Endocrinology 118, 183-188. doi: 10.1210/endo-1181-183

Kim, H. J. (1994). Mechanisms of hyperkalemia associated with hyporeninemic hypoaldosteronism in streptozotocin-induced diabetic rats. J. Korean Med. Sci. 9, 107-115. doi: 10.3346/jkms.1994.9.2.107

Krochmal, M., Kontostathi, G., Magalhães, P., Makridakis, M., Klein, J., Husi, H., et al. (2017). Urinary peptidomics analysis reveals proteases involved in diabetic nephropathy. Sci. Rep. 7:15160. doi: 10.1038/s41598-017-15359-15359

Kuhlmann, U., Vetter, W., Fischer, E., and Siegenthaler, W. (1978). Control of plasma aldosterone in diabetic patients with hyporeninemic hypoaldosteronism. Klin. Wochenschr. 56, 229-234. doi: 10.1007/BF0147 7829

Kumar, V. R. S., and Anders, H.-J. (2016). Cathepsins are potential therapeutic targets in kidney disease. Kidney Int. 90, 933-935. doi: 10.1016/j.kint.2016. 07.034

Lambers Heerspink, H. J., Perkovic, V., and De Zeeuw, D. (2009). Renal and cardioprotective effects of direct renin inhibition: a systematic literature review. J. Hypertens. 27, 2321-2331. doi: 10.1097/HJH.0b013e3283310f92

Lee, M. J., Kim, S. S., Kim, I. J., Song, S. H., Kim, E. H., Seo, J. Y., et al. (2017). Changes in urinary angiotensinogen associated with deterioration of kidney function in patients with type 2 diabetes Mellitus. J. Korean Med. Sci. 32, 782. doi: 10.3346/jkms.2017.32.5.782

Matavelli, L. C., Huang, J., and Siragy, H. M. (2012). Combined aliskiren and amlodipine reduce albuminuria via reduction in renal inflammation in diabetic rats. J. Cardiovasc. Pharmacol. 59, 281-287. doi: 10.1097/FJC.0b013e31823ffef5

Moher, D., Shamseer, L., Clarke, M., Ghersi, D., Liberati, A., Petticrew, M., et al. (2016). Preferred reporting items for systematic review and meta-analysis protocols (PRISMA-P) 2015 statement. Rev. Esp. Nutr. Humana Diet. 4:1. doi: 10.1186/2046-4053-4-1

Nehme, A., Zouein, F. A., Zayeri, Z. D., and Zibara, K. (2019). An update on the tissue renin angiotensin system and its role in physiology and pathology. J. Cardiovasc. Dev. Dis. 6, 1-17. doi: 10.3390/jcdd6020014 
Nussberger, J., Wuerzner, G., Jensen, C., and Brunner, H. R. (2002). Angiotensin II suppression in humans by the orally active renin inhibitor Aliskiren (SPP100): comparison with enalapril. Hypertension 39, E1-E8. doi: 10.1161/hy0102. 102293

Parving, H.-H., Brenner, B. M., McMurray, J. J. V., de Zeeuw, D., Haffner, S. M., Solomon, S. D., et al. (2009). Aliskiren trial in type 2 diabetes using cardio-renal endpoints (ALTITUDE): rationale and study design. Nephrol. Dial. Transplant. 24, 1663-1671. doi: 10.1093/ndt/gfn721

Parving, H.-H., Brenner, B. M., McMurray, J. J. V., de Zeeuw, D., Haffner, S. M., Solomon, S. D., et al. (2012). Cardiorenal end points in a trial of aliskiren for type 2 diabetes. N. Engl. J. Med. 367, 2204-2213. doi: 10.1056/NEJMoa1208799

Parving, H.-H., Persson, F., Lewis, J. B., Lewis, E. J., and Hollenberg, N. K. (2008). Aliskiren Combined with losartan in Type 2 diabetes and nephropathy. N. Engl. J. Med. 358, 2433-2446. doi: 10.1056/NEJMoa0708379

Paulsen, E. P., Seip, R. L., Ayers, C. R., Croft, B. Y., and Kaiser, D. L. (1989). Plasma renin activity and albumin excretion in teenage type I diabetic subjects a prospective study. Hypertension 13, 781-788. doi: 10.1161/01.HYP.13.6.781

Perez, G. O., Lespier, L., Jacobi, J., Oster, J. R., Katz, F. H., Vaamonde, C. A., et al. (1977). Hyporeninemia and hypoaldosteronism in diabetes mellitus. Arch. Intern. Med. 137, 852-855. doi: 10.1001/archinte.137.7.852

Persson, F., Lewis, J. B., Lewis, E. J., Rossing, P., Hollenberg, N. K., and HansHenrik, P. (2012a). Impact of aliskiren treatment on urinary aldosterone levels in patients with type 2 diabetes and nephropathy: an AVOID substudy. JRAAS J. Renin Angiotensin Aldoster. Syst. 13, 118-121. doi: 10.1177/1470320311417272

Persson, F., Lewis, J. B., Lewis, E. J., Rossing, P., Hollenberg, N. K., and Parving, H. H. (2012b). Impact of glycaemic control on the effect of direct renin inhibition in the AVOID study. JRAAS J. Renin Angiotensin Aldoster. Syst. 13, 250-253. doi: 10.1177/1470320312437068

Persson, F., Lewis, J. B., Lewis, E. J., Rossing, P., Hollenberg, N. K., and Parving, H.-H. (2010). Impact of baseline renal function on the efficacy and safety of aliskiren added to losartan in patients with type 2 diabetes and nephropathy. Diabetes Care 33, 2304-2309. doi: 10.2337/dc10-0833

Persson, F., Lewis, J. B., Lewis, E. J., Rossing, P., Hollenberg, N. K., and Parving, H. H. (2011). Aliskiren in combination with losartan reduces albuminuria independent of baseline blood pressure in patients with type 2 diabetes and nephropathy. Clin. J. Am. Soc. Nephrol. 6, 1025-1031. doi: 10.2215/CJN. 07590810

Persson, F., Rossing, P., Reinhard, H., Juhl, T., Stehouwer, C. D. A., Schalkwijk, C., et al. (2009). Renal effects of aliskiren compared with and in combination with irbesartan in patients with type 2 diabetes, hypertension, and albuminuria. Diabetes Care 32, 1873-1879. doi: 10.2337/dc09-0168

Phelps, K. R., Lieberman, R. L., Oh, M. S., and Carroll, H. J. (1980). Pathophysiology of the syndrome of hyporeninemic hypoaldosteronism. Metabolism 29, 186-189. doi: 10.1016/0026-0495(80)90145-90146

Pratt, J. H., Parkinson, C. A., Weinberger, M. H., and Duckworth, W. C. (1985). Decreases in renin and aldosterone secretion in alloxan diabetes: an effect of insulin deficiency. Endocrinology 116, 1712-1716. doi: 10.1210/endo-116-51712

Rafiq, K., Hitomi, H., Nakano, D., Ichihara, A., and Nishiyama, A. (2011). Possible involvement of the (pro)renin receptor-dependent system in the development of insulin resistance. Front. Biosci. 3, 1478-1485. doi: 10.2741/238

Saito, T., Kobori, H., Urushihara, M., Kotani, Y., and Kagami, S. (2009). Increased urinary angiotensinogen is precedent to increased urinary albumin in patients with type 1 diabetes. Am. J. Med. Sci. 338, 478-480. doi: 10.1097/MAJ. 0b013e3181b90c25

Sealey, J. E., and Laragh, J. H. (2009). Aliskiren fails to lower blood pressure in patients who have either low PRA levels or whose PRA falls insufficiently or reactively rises. Am. J. Hypertens. 22, 112-121. doi: 10.1038/ajh.2008.275

Şen, S., Sabırlı, S., Özyiğit, T., and Üresin, Y. (2013). Aliskiren: review of efficacy and safety data with focus on past and recent clinical trials. Ther. Adv. Chronic Dis. 4, 232-241. doi: 10.1177/2040622313495288

Sousa, L. S., de Sousa, A. G. P., Nunes, A. B., Cabral, J. V., de, S., and El-Feghaly, W. B. (2016). Hyporeninemic hypoaldosteronism and diabetes mellitus: pathophysiology assumptions, clinical aspects and implications for management. World J. Diabetes 7, 101-111. doi: 10.4239/wjd.v7.i5.101

Stanton, A. (2003). Potential of renin inhibition in cardiovascular disease. JRAAS J. Renin Angiotensin Aldoster. Syst. 4, 6-10. doi: 10.3317/jraas.2003.008
Stanton, A. V., Dicker, P., and O’Brien, E. T. (2009). Aliskiren monotherapy results in the greatest and the least blood pressure lowering in patients with high- and low-baseline PRA levels, respectively. Am. J. Hypertens. 22, 954-957. doi: 10.1038/ajh.2009.114

Tuck, M. L., Sambhi, M. P., and Levin, L. (1979). Hyporeninemic hypoaldosteronism in diabetes mellitus. Studies of the autonomic nervous system's control of renin release. Diabetes 28, 237-241. doi: $10.2337 /$ diab.28.3.237

Uresin, Y., Taylor, A. A., Kilo, C., Tschöpe, D., Santonastaso, M., Ibram, G., et al. (2007). Efficacy and safety of the direct renin inhibitor aliskiren and ramipril alone or in combination in patients with diabetes and hypertension. JRAAS J. Renin Angiotensin Aldoster. Syst. 8, 190-198. doi: 10.3317/jraas. 2007.028

Urushihara, M., and Kagami, S. (2017). Role of the intrarenal renin-angiotensin system in the progression of renal disease. Pediatr. Nephrol. 32, 1471-1479. doi: 10.1007/s00467-016-3449-3447

Villoria, G., Nunez, M., Miralles, J. M., del Pozo, D. C., and Romo, T. (1988). Hyporeninemic hypoaldosteronism in diabetic patients with chronic renal failure. Am. J. Nephrol. 8, 127-137. doi: 10.1159/000167571

Wang, R.-F., Podos, S. M., Serle, J. B., and Baltatu, O. C. (2012). Effect of SPP 635, a renin inhibitor, on intraocular pressure in glaucomatous monkey eyes. Exp. Eye Res. 94, 146-149. doi: 10.1016/j.exer.2011.11.019

Wang, W., Qiu, L., Howard, A., Solis, N., Li, C., Wang, X., et al. (2014). Protective effects of aliskiren and valsartan in mice with diabetic nephropathy. JRAAS J. Renin Angiotensin Aldoster. Syst. 15, 384-395. doi: 10.1177/14703203135 07123

Watanabe, T., Waguri, S., Watanabe, M., Ishii, Y., Kominami, E., and Uchiyama, Y. (1989). Immunocytochemical localization of angiotensinogen and cathepsins $\mathrm{B}, \mathrm{H}$, and $\mathrm{L}$ in rat hepatocytes, with special reference to degradation of angiotensinogen in lysosomes after colchicine. J. Histochem. Cytochem. 37, 1899-1911. doi: $10.1177 / 37.12 .2685113$

Weidmann, P., Reinhart, R., Maxwell, M. H., Rowe, P., Coburn, J. W., and Massry, S. G. (1973). Syndrome of hyporeninemic hypoaldosteronism and hyperkalemia in renal disease. J. Clin. Endocrinol. Metab. 36, 965-977. doi: 10.1210/jcem-36-5-965

Wood, J. M., and Close, P. (1996). Renin inhibitors: cardiovascular drugs of the future? Cardiovasc. Drugs Ther. 10, 309-312. doi: 10.1007/bf02627954

Wood, J. M., Maibaum, J., Rahuel, J., Grütter, M. G., Cohen, N. C., Rasetti, V., et al. (2003). Structure-based design of aliskiren, a novel orally effective renin inhibitor. Biochem. Biophys. Res. Commun. 308, 698-705. doi: 10.1016/S0006291X(03)01451- 1457

Yacoub, R., and Campbell, K. N. (2015). Inhibition of RAS in diabetic nephropathy. Int. J. Nephrol. Renovasc. Dis. 8, 29-40. doi: 10.2147/IJNRD.S37893

Zheng, S. L., Roddick, A. J., and Ayis, S. (2017). Effects of aliskiren on mortality, cardiovascular outcomes and adverse events in patients with diabetes and cardiovascular disease or risk: a systematic review and meta-analysis of 13,395 patients. Diabetes Vasc. Dis. Res. 14, 400-406. doi: 10.1177/1479164117715854

Zhou, G., Liu, X., Cheung, A. K., and Huang, Y. (2015). Efficacy of aliskiren, compared with angiotensin ii blockade, in slowing the progression of diabetic nephropathy in $\mathrm{db} / \mathrm{db}$ mice: should the combination therapy be a focus? Am. J. Transl. Res. 7, 825-840.

Zimpelmann, J., Kumar, D., Levine, D. Z., Wehbi, G., Imig, J. D., Navar, L. G., et al. (2000). Early diabetes mellitus stimulates proximal tubule renin mRNA expression in the rat. Kidney Int. 58, 2320-2330. doi: 10.1046/j.1523-1755.2000. 00416.x

Conflict of Interest: The authors declare that the research was conducted in the absence of any commercial or financial relationships that could be construed as a potential conflict of interest.

Copyright (c) 2020 Massolini, Contieri, Lazarini, Bellacosa, Dobre, Petroianu, Brateanu, Campos and Baltatu. This is an open-access article distributed under the terms of the Creative Commons Attribution License (CC BY). The use, distribution or reproduction in other forums is permitted, provided the original author(s) and the copyright owner(s) are credited and that the original publication in this journal is cited, in accordance with accepted academic practice. No use, distribution or reproduction is permitted which does not comply with these terms. 